\title{
ISLAMIC THEOLOGICAL DOGMAS BETWEEN MUSLIM RATIONALISTS AND TRADITIONALISTS
}

\author{
By: Ibrahim Abu Bakar*
}

Paper ini mencoba melihat perbedaan cara berteologi dalam Islam yang dianut oleh muslim rasionalis atau mu'tazilah dan muslim tradisionalis atau Asy'ariyah. Menurut penulis, ada beberapa poin yang patut diperhatikan dalam melihat perbedaan ideologi dogma yang dipegang oleh masing-masing kelompok ini. Pertama, masing-masing kelompok sama-sama menjadikan al Qur'an sebagai rujukan mereka ketika menerima atau menolak suatu dogma teologis tertentu. Kedua, kaum rasionalis menolak klaim bahwa al Qur'an itu tidak diciptakan dan kemampuan untuk melihat Tuhan sebagaimana yang diyakini oleh kaum tradisionalis. Ketiga, munculnya perbedaan dari kaum rasionalis dan tradisionalis dalam upaya mereka untuk menerima atau menolak dogma teologis tertentu terkadang karena penyandaran pada kata yang sama dengan pemaknaanyang berbeda atau perbedaan dalam merujuk suatu ayat.

\section{0}

إن هذه الدراسة تحاول النظر إلى التفريق يين الطرق لدراسة" اللاهوتية في الإسلام التي

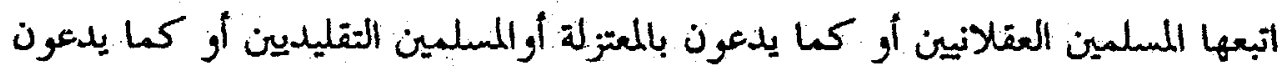

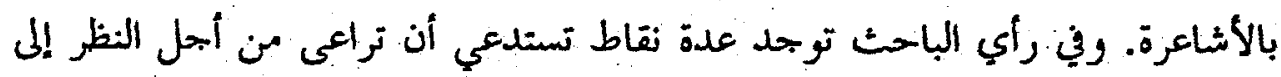
التفرتة الأيدولوجية بين الطائفتين مثل : إن كل من البحموعتين اعتبروا القرآن مر.بعهم عندلا يقبلون أر يرفضون احلدى مبادئ اللاهوتية، وإن العقلانيين يؤمنون في فكرة نحلق القرآن ويشكك في القدرة على زؤية التحالت كما يصورها التقليديون. إن ظهور الانحتلاف الواضح بين الفثة العقلانية والفئة التي ترغب بي إعادة التقليدية في طريقتهم بقبول أو رفض نكرة لاهوتية معينة وذلك لإسناد غلى كلمة معينة في حقيقتها تحمل عدة معاني مختلفة أو الختلاف في العودة لاحلدى الآيات.

Keywords: Theology, the Qur'an, the Beatific Vision, Mu tazilite, al-Ash ari

"Professor of Universiti Kebangsaan Malaysia(UKM) 


\section{A. Introduction}

The main sources of Islamic theological dogmas are two namely the Qur'an and the Tradition of the Prophet Muhammad or the Hadits or Sunnah. Both sources are considered as the most authoritative and authentic references for Islamic theological dogmas. Some of the Arabic terms for Islamic theological dogmas are arkân al-îman (the pillars or articles of faith), ushûl al-din (the principles of religion), ushûl al-dîn al-islâmiyy (the principles of Islamic * religion) and al- 'aqấ'id al-islâmiyyah (Islamic dogmas or doctrines). Seyyed Hossein Nasr uses the Arabic term ushûl al-dîn for the principles of religion. He writes, "The five principles of religion (ushûl al-dîn) as stated by Shi" ism include: tawhîd or belief in Divine Unity; nubuwwah or prophecy; ma'ad or resurrection; imâmah or the Imamate, belief in the Imams as successors of the Prophet; and 'adl or Divine Justice."'

Muslims who have made serious and rigorous efforts to understand and interpret both the Qur'an and the Prophet tradition can be broadly divided into different classes of Muslim religious scholars or Muslim ulema such as theologians, sufis, jurists, traditionists, and philosophers. Among Muslim theologians, they can be further classified into different groups such as the Jabarites, the Qadarites, the Murjiites, the Kharijites, the Shi'ites, the Mu'tazilites, the Hanbalites, the Ash'arites, the Maturidites, the Salafites or Salafis and the Sunnites. For the purpose of this paper, the Mu'tazilites are considered as Muslim rationalists and their opponents as Muslim traditionalists.

In Muslim theological history, the Mu'tazilites are considered "the first articulate theological movement in Islam"2; they are well known for their admiration and advocation of the rational, intellectual and ethical methods in their understanding and interpreting Muslim theological dogmas or doctrines.

- The Mu'tazilites agreed with the Qadarites on human free action and diametrically opposed the Jabarites or the Determinists who advocated God's strict predestination of all events in the universe including human actions. The Umayyad Dynasty is reported to rely on the Jabarite notion of God's predestination in the sense that the Umayyads are predestined by God to be the Muslim caliphs or rulers and their actions are also predestined by God whether their actions are just and unjust. God's predestination is instrumental for the Umayyads to legitimize their rulings and actions against their opponents and adversaries such as the Kharijites and the Shi ites as well as other Muslim groups. The Shi' ites give their ultimate preference to the descendents of Ali bin

\footnotetext{
' Seyyed Hossein Nasr, No date. "Preface" in Shi ite Islam .by Sayyid Muhammad Husayn Tabatabai, Translated from Persian and edited with an intoduction and notes by Seyyed Hossein Nasr. Houston: Free Islamic Literatute, Inc., p.Ế11.

${ }^{2}$ Majid Fakhry, 1997, A Short Introduction to Islamic Philosophy, Theology and Mysticism, Oxford: Oneworld Publications, p.Ê16.
} 
A.bi Thalib to lead the Muslim community. The Kharijites are known for their radical opposition to the Umayyad caliphs and their governors. The Kharijites are considered to be the defenders of political egalitarianism among Muslims. Political egalitarianism is not at par with political elitism advocated by the Umayyads and the Shi ites.

There were other Muslims who did not approve the unjust actions of the Umayyad caliphs and governors. One of such Muslims was Hasan al-Bashri (d. 728) in Basra. He did not agree with the Muslims who imputed the responsibility for their evil actions or wrong doings to God and he categorically rejected the claims of the advocates of God's predestination on human actions. The Mu'tazilites agree with the Qadarite notion of human freedom in their actions and it becomes the Mu tazilite hallmark. During the Abbasid Caliphate especially during the reigns of the three Caliphs namely al-Ma'mun, alMu'tasim and al-Wathiq, from 198A.H./813 A.C. to 232/846, the Mu'tazilites were dominant and powerful. The three caliphs and their high ranking administrators strongly supported the Mu'tazilite dogmas. One of them was accepted as the state theological dogma and the Caliph al-Ma'mun decreed that all Muslims should believe in that dogma namely the createdness of the Qur'an. The Mu'tazilites uphold that the Qur'an is created by God and hence it is one of God's creation and not eternal. It is not eternal since the only eternal being is God. The Qur'an is temporal and perishable like other God's created beings. Moreover, the Qur'an is touchable, readable and destructible. It consists of Arabic letters and sentences. This means that the Qur'an is not eternal like God. God is eternal, unseen, untouchable and indestructible. Human beings cannot destroy God but God can destroy them as He has created them since He is the Omnipotent.

The Muslims who opposed the createdness of the Qur'an during the Abbasid Dynasty were led by Ahmad bin Hanbal (d. 855). He was known for his staunch advocate of the uncreatedness of the Qur'an. He was asked to accept the state. theological dogma of the createdness of the Qur'an but he refused and upheld his own conviction that the Qur'an was God's speech, uncreated and eternal. He was arrested and punished but still refused to follow the order to change his conviction about the nature of the Qur'an. He faced the terrible consequence of his belief in the eternal Qur'an during the famous Mihnah or the theological inquisition set up and ordered by the Caliph al-Ma'mun, in 825 and 833, and followed by his two immediate successors namely al-Mu tasim and al-Watsiq. Majid Fakhry writes about the Mu'tazilite supremacy and downfall in the following statements: " $\mathrm{Mu}$ " tazilite theological ascendancy continued during the reign of al-Ma mun and his two immediate successors; but with the accession of al-Mutawakkil in 847 , the official policy of the state was completely reversed. Ibn Hanbal was released from prison and amends made to him; a new policy of 
repression aimed at the Mu'tazilah, the Shi'ah and others was inaugurated. From that time on, the star of the Mu' tazilah began to set."

The emergence of the Mu'tazilites and their opponents represented mainly by the Hanbalites, the traditionists and jurists, during the Abbasid dynasty can be seen as the emergence of two Muslim theological schools namely Muslim rationalists and traditionalists. The rationalists uphold the importance of human reason in understanding and accepting Islamic theological doctrines. They assert that Islamic theological dogmas should not be in contrary with what is judged acceptable and reasonable by human reason. On the contrary, the traditionalists stress that human reason should accept whatever dictated by the Divine revelation found in the Qur'an and the Prophetic tradition and their approaches are literal and lexical. They emphasize on accepting the literal meanings of the Prophethic traditions and the Qur'anic verses related to Islamic theological dogmas. The Muslim traditionalists have dominated the Muslim world after the Caliph al-Mutawakkil started opposing the $\mathrm{Mu}$ tazilites and supporting Ahmad bin Hanbal and his followers in 238A.H./848 A.D. The Hanbalites were then very powerful. This is evident from the case of Abu Hasan al-Ash ari (d. 324/935) who withdrew from his. Mu'tazilite teacher Abu Ali alJubba $i$ (d. 303/915), the head of the Mu'tazilite branch in Basrah. He does not have other alternative but to seek support from the Hanbalites. In his al-Ibânah, al-Ash ari acknowledges that "the belief we uphold and the religion we follow are holding fast to the Book of our Lord, to the Sunnah of our Prophet and to what was reported by the leading Companions, the Successors and the leaders of the tradition and to all those we hold firmly as well as to what was said by Abu 'Abd Allah Ahmad bin Muhammad bin Hanbal.... because he is the honoured imam and the prefect leader whom Allah explained the truth when the heresy emerged and he then explained the method to the truth and with it he subdued the innovations of the innovators, the deviations of the deviators and the doubts of the doubters...". ${ }^{4}$

Hamad bin Muhammad al-Ansari who introduced al-Ibânah for its second edition writes that Abu Hasan al-Ash ari returned from the Mu'tazilites to the Salafite faith, aqidah al-salaf. (al-Ansari 1990: 8). The first chapter of AlAsh'ari's Ibanah is to explain the view or opinion of the deviated and heretical people, fi ibânah qawl ahl-al-zaygh wa al-bid'ah. They are the Mu'tazilites and the Qadarites who have deviated from the truth and tended to blindly following their leaders and their previous leaders and they interpreted the Qur'an according to their opinions, the interpretation that Allah does not authorize, and it is not explained by any proof, not transmitted from the Prophet of the Lord of

\footnotetext{
${ }^{3}$ Ibid., p. 20

"Abu al-Hasan 'Ali bin Isma il Al-Ash`ari, 1990, al-Ibânah 'an Ushul al-Dìânah. Edited by Bashir Muhammad 'Uyun. Dimshiq: Maktabah Dar al-Bayan, p. 43.
} 
the universe, not taken from al-salaf al-mutaqaddimin (the previous or earlier Salafites). The Mu'tazilites and the Qadarites do not agree.with the reports of the Companions who narrated from the Prophet regarding seeing Allah with eyes, "u'yatullah bi al-absâr; they disbelieve in the intercession of the Prophet for the sinners; they deny the punishment in the grave which is agreed upon by the Companions and Successors that the disbelievers are punished in their graves; they uphold the createdness of the Qur'an; they affirm and believe that human beings and satans create the evil, al-syar, and Allah creates the good, al-khayr. There are many other beliefs upheld and defended by the Qadarites and Mu'tazilites according to al-Ash ari and he concludes the first chapter by stating that all innovators from the Jahmites, the Murjiites, the Harurites, the Qadarites and the Mu'taziltes are the deviated people since they have innovated and deviated from the Qur'an and the Sunnah and from what had been followed by the Prophet and his Companions and agreed upon by the Muslim community. ${ }^{6}$ It is clear from al-Ash ari's conclusion of the first chapter that the sources for Islamic theological dogmas are four namely the Qur'an, the Sunnah, the Companions and the Consensus of Muslim community.

The second chapter of al-Ash 'ari's Ibânah is to explain the view or opinion of the people of the truth and the Sunnah, fi ibânah qawl ahl al-haqq wa-al-sunnah. It begins with the statement saying that " if someone tells us that you have rejected the view of the Mu'tazilites, the Qadarites, the Jahmites, the Harurites, the Rafidites and the Murjiites, hence explain to us your view which you uphold and your religious beliefs which you believe in them". After explaining the sources of the religion which upheld by the people of the truth and of the Sunnah namely the Qur'an, the Sunnah, the reports from the leading Companions, Successors and the imams of the Prophetic traditions including Imam Ahmad bin Hanbal, al-Ash'ari explains that the people of the truth and the Sunnah are contented or satisfied with Allah, His angels, His books and His messengers and what came from Allah and what reported by the reliable reporters from the messenger of God and God is one, and He has no friend and son and Muhammad is His servant and messenger and He sent him with the guidance and the true religion. They also uphold that God's speech is not created and the Qur'an is God's speech which is not created, and God is seen by the eyes in the hereafter as the eyes see the moon during the night of the full moon, and God is seen by the believers, al-mu 'minûn, as reported by many reporters from the messenger of God, rasûlullah. The unbelievers cannot see God. The Prophet Musa asked God to be seen in this world and he could not see Him in this world. ${ }^{8}$ As regard the

\footnotetext{
${ }^{5}$ Ibid., p. 38-39.

'Ibid., p. 42.

'Ibid., p. 43-44.

${ }^{8} \mathrm{Ibid.}$., p. 45 and $47-48$.
} 
intercession of the Prophet Muhammad for some Muslim sinners in the hereafter, al-Ash ari states that God would take out a group of people from the Hell with the intercession of Muhammad, God's messenger as reported by many reporters about the subject. ${ }^{9}$

Even though there are many theological dogmas held by the people of the truth and the Sunnah as explained by al-Asha'ari, the focus of this paper are two namely the Qur'an and the beatific vision. The two are selected as the examples in showing the differences between Muslim rationalists and traditionalists in their understanaing and interpretation. Muslim rationalists do not believe in the uncreatedness of the Qur'an and the beatific vision. Meanwhile Muslim traditionalists believe in those two theological dogmas.

\section{B. The Qur'an}

As explained above, the Qur'an is believed to be the main revealed source for Islamic theological dogmas. Muslims believe that the Qur'an was revealed by God to His Prophet Muhammad who then read the Qur'an to his community. The Qur'an is different from the Prophetic tradition since the former was revealed in verbatum to the Prophet Muhammad while the latter. its meanings were revealed to the Prophet and the words and sentences were from the Prophet. Muslim rationalists and traditionalists agree that the Qur'an is the main source of Islamic theological dogmas.

The relationship between the Qur'an and God's speech is understood differently by Muslim rationalists and traditionalists. The former maintain that the Qur'an is God's created speech while the latter uphold that the Qur'an is God's uncreated speech. Muslim theologian Abu Hasan al-Ash 'ari (d. 935) was in agreement with Ibn Hanbal (d. 855) regarding the uncreatedness of the Qur'an. The fourth chapter of al-Ash ari's Ibânah is on the Qur'an which is God's uncreated speech. He cites many Qur'anic verses to support his understanding and interpretation for that belief. Some of those Qur'anic verses are from Surah al-Rûm (30: 25), Surah al-A'araf (7: 54), Surah al-Baqârah (2: 97), Surah alNahl (16: 40), Surah al-Kahfi (18: 109), Surah al-Sajdah (32: 13) and Surah alMudaththir (74:25), and Surah al-Anbiyâ (21:62-63) (al-Ash`ari 1990: 72-76) Those Qur'anic verses are cited and interpreted by al-Ash ari to prove his conviction that the Qur'an is God's uncreated speech.

Some of his interpretations of those Qur'anic verses are presented here. AlAsh'ari cites the Qur'an (30:25) which says "And among His signs is this, That heaven and earth Stand by His command...", the Qur'anic word bi-amrih is interpreted by al-Ash ari to mean God's speech and word, and when $\mathrm{He}$ commanded both the heaven and the earth to stand, they stand. Al-Ash ari also

\footnotetext{
${ }^{9} I b i d .$, p. 49.
} 
cites the Qur'an (7: 54) which says, "...Verily, His are the Creation and the Command..." which is understood by al-Ash ari to mean two different things. First, it is God's created universe and everything created within it. Second, God's command is not among God's created universe. This proves that God's command is uncreated: God's command is His speech and this is necessary that God's speech is uncreated. ${ }^{10}$

Regarding the generality and specificity of certain Qur'anic verses, alAsh ari replies that "We specify or particularize the Qur'an with the Consensus and the dalil (proof or evidence)". To support his view, al-Ash ari cites the Qur'an (2:98) which means "Whoever is an enemy to Allah and His angels and prophet, to Gabriel and Micheal..." His interpretation of that Qur'anic verse is that Gabriel and Micheal are not included in the angels even though they are among the angels since they are to be mentioned and particularized later on after mentioning the angels in general. For him, however, the Qur'an (7:45) is different from the Qur'an (2: 98). The latter is not about the generality and specificity as the former. It is about two different things namely the creation and the unreated word of God, al-khalq wa-al-amr. The Qur'an $(7: 45)$ is supported by the Qur'an (30:4) which means "... with Allah is the Command in the Past and in the Future..." Al-Ash ari intepreted it to mean God's command has existed before $\mathrm{He}$ creates His creation and after $\mathrm{He}$ creates His creation. Hence the Command is uncreated. ${ }^{11}$

The Qur'anic verses which al-Ash ari cites and interprets to prove his * conviction that the Qur'an is the uncreated word of God are in the fourth chapter of the Ibânah. His quotations of the Qur'anic verses and interpretations are aimed at refuting and rejecting the Jahmite view that the Qur'an is the created word of God. He makes mention many times the Jahmites and their beliefs. AlAsh ari writes that what is claimed by the Jahmites is similar with what is claimed by the Christians because the Christians claim that the word of God is included in Mary's or Maryam's womb, and the Jahmites add to that and they claim that God's speech was created and occupied a tree (syajarah) and that tree contained God's speech. This necessarily led them to hold that that tree is a speaking tree and they are compelled to admit that a certain created being like that tree spoke to Moses saying, "Oh Moses! Verily I am God; there is no god but $\mathrm{Me}$, hence worship Me". If the speech of God, kalâmullah, were created in a tree, it would necessarily the created said "Oh Moses! Verily I am God, there is no God but Me, hence worship me". Mean while God said in the Qur'an (32: 13) saying "... But the Word from me will come true. 'I will fill Hell with Jinns and men all together." Therefore, God's speech is from God and it is impossible that His speech which is from Him is created in a created tree as it is impossible for

\footnotetext{
${ }^{10}$ Ibid., p. 72.

"Ibid., p. 72-73.
} 
His knowledge which is from Him is created in something other than Himself. God highly and greatly transcends from all that. Therefore, it is impossible for God to create His speech in a created being for the reason that created being. would necessarily be the speaker of His speech and it is impossible for God's speech to be the speech of the created being. ${ }^{12}$ This shows that al-Ash ari directs his theological attack to the Jahmites who hold that the Qur'an is God's created speech. He equates that view of Jahmites with the view of the Christians about the word of God, kalimatullâh, in the womb of Mary.

Al-Ash ari also stresses that the view upheld by the Jahmites namely God's speech is created would compel them to make God speechless like the idols which do not talk and speak About the speechless idols, the Qur'an (21:62-63) describes about them and the Prophet Ibrahim who argues that since those idols are speechless, they are not gods. Therefore, God is a speaking being since eternity. ${ }^{13}$

Al-Ash ari refutes the Jahmite view regarding the createdness of God's speech by using his own rational arguments. He argues that the created being is either a body of human bodies or an attributc of human attributes. God's speech cannot be a person since persons are possible to eat, drink and marry, which are not possible for God's speech. God's speech cannot be an attribute of a created person since the attribute does not persist for the twinkling of an eye because the attribute does not remain for long and this necessarily makes God's speech perish and annihilate. Hence if it is impossible for God's speech to be a person or an attribute of a person, it is impossible to be a created being. If God's speech were created, it would be a body or an attribute of a body. If it were a body, it would be a speaker and God is capable for changing them. This compels the Jahmites to think about the possibility that God changes the Qur'an to a human being or a satan. God's speech transcends all of them. ${ }^{14}$

The fifth chapter of the same work contains the reports from Muslim leaders who uphold the view that the Qur'an is God's uncreated speech. For example, alAsh ari cites the report from Ahmad bin Hanbal saying that " What I believe and hold without any doubt is the Qur'an is uncreated." Ibn Hanbal is reported to base his belief on the Qur'an (7:54) and the Qur'an (55: 13). For Ibn Hanbal, the Qur'an is part of God's knowledge as He says in the Qur'an (55:2) saying "It is He Who has taught the Qur-an".(al-Ash"ari 1990: 85). Al-Ash ari cites the report from Sulayman bin Harb who holds that the Qur'an is uncreated. He bases his view on the Qur'an (3:77) saying "... Nor will Allah (deign to) speak to them or look at them..." which is interpreted that God's word and look have the same meaning i.e. uncreated. ${ }^{15}$

\footnotetext{
12Ibid., p. 74-75.

${ }^{13}$ Ibid., p. 76.

is Ibid., p. 83-84.

15 Ibid., p. 88.
} 
Muslim rationalists agree with Muslim traditionalists regarding the source and purposes of the Qur'an. Both groups agree that God is the source of the Qur'an and it was revealed to the Prophet Muhammad to guide human beings to God. 'Abd al-Jabbâr bin Ahmad (d. 415 A.H./1025 A.C), a Mu'tazilite and a Muslim rationalist, in this context writes that our school holds that the Qur'an is God's speech and His revelation, it is created (makhlûq muhdats) and God revealed the Qur'an to His prophet as an indication and proof to his prophethood and God made the Qur'an dalâlah (sign, guidance) for us regarding al-ahkâm (regulations, provisions or laws) for us to refer to the Qur'an for the lawful and the unlawful, and it is obligatory upon us to thank, praise and sanctify Him for His revelations in the Qur'an. Therefore, the Qur'an which we read and listen to it is connected with God. ${ }^{16}$

Muslim rationalists utilize the rational and textual proofs to refute the view which says that the Qur'an is God's uncreated speech. They consider that those who hold such view is the most ignorant people since the Qur'an preceded one upon the other and what was in that way was impossible to be eternal because the eternal one was not preceded by the other. For example the letter hamzah in the word al-hamdulillâh preceded the letter lam and the letter lam preceded the letter.ha. All this does not show that it is eternal. That is the situation hal in the Qur'an. Its sentences have beginning and ending, some precede some others. The Qur'an with that attribute is impossible to be eternal. ${ }^{17}$ The textual proofs used by Muslim rationalists are from the Qur'anic'verses which are understood and interpreted to be on their side such as the Qur'an $(21: 2,15: 9,11: 1$, and 39: 23). ${ }^{18}$

\section{The Beatific Vision}

The third chapter of al-Ash ari's Ibanah is on the beatific vision. The title of the chapter is al-kalâm fi ithbat ru yatullah ta'ala bi-al-bashâr fi al-akhirah. That title was the translated by Walter C. Klein as "the Kalam to Prove the Visibility of God to Sight (Abshâr) in the Next World.",

To prove the possibility of looking at God in the Paradise, al-Ash ari who represented Muslim traditionalists refers to the Qur'an (75: 23-24) saying "Some faces, that Day, will beam (in brightness and beauty); Looking towards their Lord." The Arabic word in that Qur'anic verse is nazhirah. For al-Ash ari and Muslim traditionalists, the word nazhirah means seeing God with human

\footnotetext{
${ }^{16}$ Ahmad, 'Abd al-Jabbar, 1988, Syarh al-Ushûl al Khamsah. Edited and introduced by Dr. 'Abd alKarim 'Uthman. al-Qahirah: Maktabah Wahbah, p.Ê528.

${ }^{17}$ Ibid., p. 531.

${ }^{18}$ Ibid., p. 531-532.

${ }^{19}$ Walter C. Klein, 1967, Abu'l-Hasan Ali ibn Isma'il al-As ari's al-Ibânah an Ushul ad-Diyânah (The Elucidation of Islam's Foundation). Translated, introduced and noted by W. C. Klein. New York: Kraus Reprint Corporation, p. 56.
} 
eyes. Although they acknowledge that the word nazhirah has many meanings but they emphasize that particular meaning for the Qur'an (75:23). The other meanings of the nazhirah are reflecting, waiting and al-ta attuf (gracefulness). Al-Ash ari cites the Qur'an (88: 17, 36: 49 and 3: 77) to provide the textual proofs for the nazhirah to mean reflecting, waiting and gracefulness respectively: He does not consider any of those three meanings of the nazhirah suitable and appropriate for the nazhirah in the Qur'an (75:24). He refutes the meaning assigned by the Mu'taziltes to the Qur'an (75:24). The Mu'taziltes, according to al-Ash'ari, interpret the nazhirah in the Qur'an (75:24) to mean waiting. For al-Ash ari, the literal and apparent meaning for the nazhirah in the Qur'an (75:24) is no other than seeing or looking at God with eyes. It is not possible for the Arabs to say nazhara ila if they mean waiting for that word. They use nazhara without ila when they want to mean waiting. ${ }^{20}$

'Abd al-Jabbâr and other Muslim rationalists cannot agree with Muslim traditionalists' interpretation of the nazhirah in the Qur'an (75: 24). Muslim rationalists dispute their understanding and interpretation to prove the ' possibility of seeing God by the inhabitants of the Paradise. Muslim rationalists maintain that it is impossible for human being beings to see God in this world as well as in the hereafter. To support their view, Muslim rationalists rely on the Qur'anic verses which are understood and interpreted to mean the impossibility for human eyes to see God in this world and the hereafter. Muslim rationalists argue that Moses asked God to let him seeing Him but he was unable to see God. God did not show Himself to Moses. The story relating that Moses was unable to see God is in the Qur'an (7: 143). Muslim rationalists also cite the Qur'an (6: 103) saying "No vision can grasp Him but His grasp is over all vision; He is subtle well-aware" to prove their point that it is impossible for human beings to see God with their eyes. ${ }^{21}$

In addition to the textual evidences from those Qur'anic verses, Muslim rationalists also advance their rational proofs to deny what is held by Muslim traditionalists as regard the beatific vision in the hereafter. They argue that if man reflects or thinks about God, he knows or realizes that what is possible for bodies such as al-mujâwarah, al-muqâbalah, al-mumâsah and al-hulûl is not possible for God. Hence that man evidently acknowledges that God cannot be seen by human eyes nor by any of human senses. ${ }^{22}$

\footnotetext{
${ }^{20} \mathrm{Abu}$ al-Hasan `Ali bin Isma`il Al-Ash`àri, op.cit., p. 58-59).

2 Abd al-Jabbar Ahmad, op.cit., p. 233.

"2I Ibid., 66.
} 


\section{i). Conclusion}

From the above discussion, it is plausible to reflect the following points:

1. Muslim rationalists and traditionalists make the Qur'an their main reference when they decide to look for their textual proofs in defending or rejecting any theological dogma.

2. Muslim rationalists do not accept the uncreatedness of the Qur'an and the beatific vision. For them the verses of the Qur'an and the rational arguments do not prove the two dogmas.

3. Muslim traditionalists accept the uncreatedness of the Qur'an and the beatific vision. For them the verses of the Qur'an and the reports which they rely on prove the two dogmas.

4. In their attempts to affirm or deny any theological dogma, both Muslim rationalists and traditionalists have either assigned the different meanings to the same words in the Qur'an or depended on the different verses of the Qur'an.

\section{BIBLIOGRAPHY}

Ahmad, 'Abd al-Jabbar, 1988, Syarh al-Ushûl al-Khamsah, Edited and introduced by Dr. 'Abd al-Karim 'Uthman. al-Qahirah: Maktabah Wahbah.

Ansari, Hamad bin Ahmad al-, 1990, "Muqaddimah al-tab'ah al-thaniyah taqdim" in al-Ibânah 'an Ushûl al-Diyânah by Abu Hasan al-Ash'ari, Dimshiq: Maktabah Dar al-Bayan.

Ash'ari, Abu al-Hasan 'Ali bin Isma'il al-, 1990, al-Ibânah 'an Ushûl alDiyânah, Edited by Bashir Muhammad 'Uyun. Dimshiq: Maktabah Dâr al-Bayan.

Fakhry, Majid, 1997, A Short Introduction to Islamic Philosophy, Theology and Mysticism. Oxford: Oneworld Publications.

Ibn Khaldun, No date, Muqaddimah Ibn Khaldun. Misr: al-Matba`ah alBahiyyah al-Misriyyah.

Klein, Walter C, 1967, Abu'l-Hasan 'Ali ibn Isma îl al-As 'ari's al-Ibânah 'an Ushul ad-Diyânah (The Elucidation of Islam's Foundation), Translated, introduced and noted by W. C. Klein. New York: Kraus Reprint Corporation. 
McCarthy, Richard J., 1953, The Theology of al-Ash 'ari, Beyrouth: Imprimerie Catholique.

Murata, Sachiko and Chittick, William C., 1996, The Vision of Islam The Foundations of Muslim Faith and Practice. London: I. B. Tauris, Publishers.

Nasr, Seyyed Hossein, No date, "Preface" in Shi ite Islam by Sayyid Muhammad Husayn Tabatabai, Translated from Persian and edited with " an intoduction and notes by Seyyed Hossein Nasr. Houston: Free Islamic Literatute, Inc.

Tabatabai, Sayyid Muhammad Husayn, No date, Shi ite Islam, Translated from Persian and edited with an introduction and notes by Seyyed Hossein Nasr. Houston: Free Islamic Literature, Inc.

Tusi, Shaykh Muhammad bin al-Hasan al-, 1986, Al-Iqtishâd fima yata allaq bi-al-I tiqâd. Bayrut: Dar al-Adwa'.

The Holy Qur-an English translation of the meanings and Commentary, Revised and edited by The Presidency of Islamic Researches, IFTA, Call and Guidance. King Fahd Holy Qur-an Printing Complex. 1410 A.H. The Qur'anic translations in this paper are from this reference. 